\title{
ANALISIS SPASIAL SEBARAN PENYAKIT MENULAR KOTA MAKASSAR TAHUN 2018
}

\author{
Spatial Analysis of the Spread of Infectious Diseases in Makassar 2018 \\ Sukarna $^{1 *}$, Awi $^{2}$, Sutamrin $^{3}$ \\ ${ }^{1}$ Prodi Matematika Jurusan Matematika, FMIPA UNM \\ ${ }^{2,3}$ Prodi Pendidikan Matematika, Jurusan Matematika, FMIPA UNM \\ Jl. Dg. Tata Raya, Kampus UNM Parangtambung, FMIPA, Makasar, Indonesia \\ e-mail: ${ }^{*}$ sukarna@unm.ac.id ; ${ }^{2}$ awi.dassa@unm.ac.id ; ${ }^{3}$ tamrin.mm@unm.ac.id
}

Corresponding author*

\begin{abstract}
Abstrak
Kepadatan penduduk berkorelasi spasial dengan berbagai aspek kehidupan masyarakat, seperti tingkat jumlah penderita penyakit menular dan non-menular, musiman atau non-musiman, ringan atau berat, dan regular atau langka. Penelitian ini fokus pada 8 penyakit menular yaitu campak, difteri, diare, typhoid, malaria, kecacingan, TB, dan DBD. Data penyakit menular 2018 diperoleh dari Kantor Dinas Kesehatan Kota Makassar yang bersumber dari 46 puskesmas seKota Makassar. Hasil atau temuan penelitian ini adalah (1) keterbatasan (pengambilan) data, sehingga, penelitian ini fokus pada 8 penyakit saja; (2) berdasar hasil analisis univariate cluster index Moran terdapat (a) dua peringkat tertinggi sebaran penyakit dikaitkan kecamatan adalah Diare di Sangkarrang, Ujungtanah, dan Mariso, dan kecacingan di Singkarang; (b) pola penyebaran penyakit menular (walau dalam artikel ini coba menampilkan hanya satu peta tematik penyakit) dan tersebar dari tidak ada signifikan sampai dengan sangat signifikan; (c) penyebaran penyakit menular nampak tidak merata disetiap kecamatan dan cenderung terjadi pada kecamatan tertentu saja, seperti (i) Campak ada 3 kecamatan (Biringkanaya, Tamalanrea, dan Bontoala), (ii) Difteri ada 2 kecamatan (Tamalanrea dan Biringkanaya), (iii) Diare hanya di Kecamatan Panakkukang, (iv) Malaria hanya di Ujungtanah, (v) Kecacingan di 4 kecamatan (Manggala, Rappocini, Makassar, dan Ujungpandang), (vi) DBD hanya di Kecamatan Panakkukang, (vii) Typhoid dan TB tak signifikan.
\end{abstract}

Kata Kunci: Analisis Spasial, Penyakit Menular, Indeks Moran

\begin{abstract}
Population density correlates spatially with various aspects of community life, such as the number of people with infectious and non-infectious diseases, seasonal (endemic) or non-seasonal (epidemic), mild or severe, and regular or rare. This research focuses on 8 infectious diseases, namely measles, diphtheria, diarrhea, typhoid, malaria, helminthiasis, TB, and DHF. Data on infectious diseases in 2018 were obtained from the Makassar City Health Service Office, which was sourced from 46 puskesmas throughout Makassar City. The results of this study are (1) The limited data, thus, this study focuses on only 8 diseases; (2) Based on the results of the analysis of univariate cluster Moran index, there are (a) the two highest warnings of disease distribution attributed to the districts, namely diarrhea (in Sangkarrang, Ujungtanah, and Mariso) and helminthiasis (in Singkarang); (b) patterns of spread of infectious diseases (this article shows only one thematic map of disease) and spread from nothing significant to very significant; (c) the spread of infectious diseases appears uneven in each district and tends to occur in certain districts, such as (i) Measles have 3 districts (Biringkanaya, Tamalanrea, and Bontoala), (ii) Diphtheria there are 2 districts (Tamalanrea and Biringkanaya), ( iii) Diarrhea only in Panakkukang District, (iv) Malaria only in Ujungtanah, (v) Worms in 4 districts (Manggala, Rappocini, Makassar, and Ujungpandang), (vi) DHF only in Panakkukang District, (vii) Typhoid and TB are not significant.
\end{abstract}

Keywords: Spatial Analysis, Infectious Diseases, Moran Index 


\section{PENDAHULUAN}

Masalah kependudukan di Indonesia semakin menantang, bukan hanya karena pendataannya tapi juga karena pertumbuhan penduduk yang semakin pesat. Indonesia menjadi negara tumbuh tercepat kedua (ratarata $1,1 \%$ selama 2000-2010)[1]. Pertumbuhan penduduk yang tinggi, bukan hanya memiliki dampak positif dalam meningkatkan jumlah tenaga kerja siap pakai namun juga memiliki dampak negatif terhadap keseimbangan lingkungan termasuk mempengaruhi budaya[2]. Pertumbuhan penduduk yang tinggi bisa mengurangi ruang perumahan yang menimbulkan suasana kumuh dan tak jarang menjadi pemicu terjadinya kemiskinan yang berakibat langsung terhadap terganggunya kesehatan masyarakat [1]-[3].

Padatnya penduduk dan kurangnya lahan yang bisa menyebabkan kemiskinan masyarakat [4], ditambah lagi sempitnya lapangan kerja akan memicu terciptanya komunitas yang kumuh dalam suatu koloni atau rumpun masyarakat [1]. Hal ini dapat mengakibatkan rentangnya penyakit mewabah dan menular pada komunitas masyarakat tersebut. Penyakit yang paling rawan terjadi adalah demam, baik demam berdarah, demam malaria, ataupun demam influenza [5]. Indonesia tercatat meningkatkan harapan hidup sebanyak delapan tahun menjadi 71,7 tahun di Tahun 1990, dan sukses menurunkan penyakit menular diare dan tuberkulosis (TBC). Namun, Indonesia saat ini juga menghadapi meningkatnya penyakit tidak menular, seperti jantungan, diabetes, stroke, dan kanker [6], [7].

Pada Tahun 2016, pada pertemuan "on the rood to universal health care in Indonesia: 1990 - 1916: a systemic analysis for the global burden of disease study" mempublikasikan 10 penyakit mematikan di Indonesia Tahun 2016 di Jurnal The Lancet. Kesepuluh penyakit tersebut adalah penyakit jantung lskemik, stroke, diabetes, tuberkulosa (TBC), sakit pinggang bawah dan nyeri leher, komplikasi disebabkan kelahiran prematur, masalah yang berhubungan dengan panca indra, cedera dan kecelakaan lalu lintas, penyakit kulit, dan penyakit yang berhubungan dengan diare [8].

Mengantisipasi penyebaran penyakit menular, Kepala Dinas Kesehatan Kota Makassar mengadakan workshop Tanggal 3 September 2019. Beliau menyatakan bahwa "Sistem kewaspadaan dini dan respon merupakan sebuah sistem yang memiliki kemampuan untuk mendeteksi dini ancaman kejadian luar biasa KLB, penyakit menular KLB menurut peraturan Menteri Kesehatan Republik Indonesia Nomor 949 tahun 2004 adalah timbulnya atau meningkatnya kesakitan atau kematian yang bermakna secara epidemiologis dalam kurun waktu dan daerah tertentu" [9].

Di samping itu, Mapping Science Committee, Rajabidfard pada tahun 2001 menerangkan mengenai pentingnya peranan posisi lokasi yaitu, (1) pengetahuan mengenai lokasi dari suatu aktifitas memungkinkan hubungannya dengan aktifitas lain atau elemen lain dalam daerah yang sama atau lokasi yang berdekatan dan (2) Lokasi memungkinkan diperhitungkannya jarak, pembuatan peta, memberikan arahan dalam membuat keputusan spatial yang bersifat kompleks [10]-[12].

Pola spasial adalah sesuatu yang berhubungan dengan penempatan atau susunan benda-benda di permukaan bumi dalam level analisis deskriptif dan pemetaan (seperti analisis visual, bobot titik) [11], [13], [14]. Setiap perubahan pola spasial akan mengilustrasikan proses spasial yang ditunjukkan oleh faktor lingkungan atau budaya. Menurut McGarigal dan Marks bahwa pola spasial adalah sebuah parameterisasi kuantitatif dari komposisi dan konfirgurasi obyek spasial. Beberapa pengujian dalam spasial autokorelasi spasial adalah Indeks Moran, Rasio Geary's, dan Local Indicator of Spatial Autocorrelation (LISA)[15][17].

Hal menarik lainnya yang dapat dilakukan guna mendukung proses analisis spasial adalah pembuatan peta tematik. Peta tematik merupakan gambaran pengelompokan atau pengklasifikasian wilayah [5]. Gambar 1 menampilkan peta tematik Kota Makassar yang terdiri atas 14 Kecamatan di Tahun 2015.

Temuan ilmiah seperti ini tentunya hanya dapat diperoleh melalui teknik dan prosedur analisis yang memenuhi syarat ilmiah. Salah satu teknik analisis yang relevan dengan masalah ini adalah analisis deskriptif spatial. Oleh karena itu, secara umum dirumuskan pertanyaan adalah "Bagaimana bentuk visualisasi karakteristik pasien dan penyebaran penyakit menular menurut kecamatan se-Kota Makassar menggunakan Analisis Spasial untuk Tahun 2018".

Tulisan ini merupakan rangkuman dari suatu hasil penelitian yang bertujuan untuk mendiskripsikan karakteristik pasien penyakit menular di Kota Makassar Tahun 2018 secara spasial. Sehingga, diperoleh (1) informasi tentang karakteristik pasien penderita delapan penyakit menular, (2) informasi pola penyebaran 
karakteristik pasien penderita delapan penyakit menular di setiap kecamatan se-Kota Makassar, (3) informasi secara visual pola penyebaran karakteristik pasien untuk salah satu penderita delapan penyakit menular, dan (4) informasi pola penyebaran dan keterkatian penyebaran delapan penyakit menular di Kota Makassar 2018.

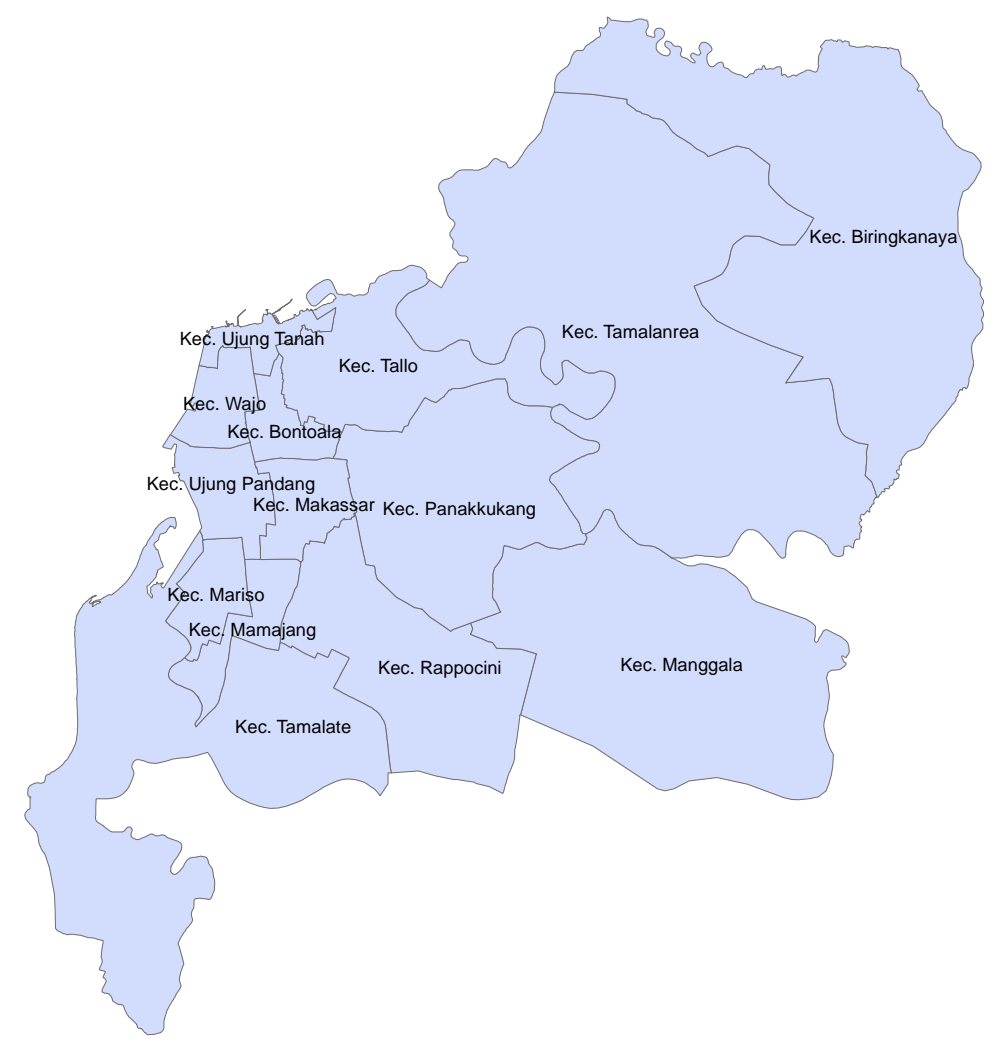

Gambar 1. Peta tematik Kota Makassar menurut Kecamatan

\section{METODE PENELITIAN}

Artikel ini diambil dari penelitian terapan dengan melibatkan banyak peubah dan menggunakan metode analisis sesuai dengan peubah dan/atau keterkaitan antar peubahnya [18], [19]. Penelitian ini melibatkan delapan peubah penyakit menular dan peubah spasial berupa daerah kecamatan se-Kota Makassar. Oleh karena itu, penelitian ini lebih menitikberatkan pada pendekatan penelitian terapan spasial deskriptif, walau dalam analisis juga melibatkan Univariate Cluster Index Moran yang didalamnya terlibat uji LISA.

Populasi penelitian ini adalah seluruh penderita penyakit menular se-Kota Makassar Tahun 2018. Adapun, sampelnya adalah yang menjalani perawatan di 46 Puskesmas se-Kota Makassar dan terekap datanya oleh Dinas Kesehatan Kota Makassar. Penelitian dilaksanakan dengan mengambil data informasi lokasi berupa peta administratif Kota Makassar dan data jumlah pasien penderita 8 penyakit menular tiap Kecamatan di Kota Makassar Tahun 2018 kemudian menganalisiskannya. Penyakit menular yang diteliti adalah Suspek Campak (SusCampak), Suspek Difteri (SusDifteri), Diare, Malaria, Kecacingan, Typhoid, Tuberkulosis (TB), dan Demam Berdarah Dengue (DBD).

\section{HASIL PENELITIAN}

Berdasarkan data ditemukan bahwa Kota Makassar terdiri dari 15 kecamatan, namun sejak tahun 2015 terdapat satu kecamatan tambahan itu adalah Kecamatan Pulau Sangkarrang atau sering juga disebut Kecamatan Sangkarrang. Dulunya, Kecamatan Ujungtanah membawahi pulau-pulau kecil diluar Pulau Sulawesi, namun di Tahun 2017, khusus untuk daerah administratif Kecamatan Ujungtanah yang berada di Pulau Sulawesi tetap menjadi bagian dari Kecamatan Ujungtanah, namun semua pulau yang diluar menjadi bagian dari Kecamatan Pulau Sangkarrang. Oleh karena itu, penelitian ini masih membawahi kedua bagian 
tersebut dimana dalam deskriptif menjelaskan 15 Kecamatan dan analisis inferensial masih menggunakan 14 kecamatan, dimana Kecamatan Ujungtanah dan Kecamatan Pulau Sangkarrang masih dimasukkan dalam kelompok Kecamatan Ujungtanah saja.

Berdasarkan kondisi lapangan dan hasil diskusi dengan pegawai penanggulangan penyakit menular Dinas Kesehatan Kota Makassar, maka penelitian ini fokus hanya pada 8 penyakit menular atau variabel yang dilibatkan dalam analisis data dan pembahasan hasil penelitian, yaitu: $X_{1}$ (SusCampak), $X_{2}$ (SusDifteri), $X_{3}$ (Diare), $X_{4}$ (Malaria), $X_{5}$ (Kecacingan), $X_{6}$ (Typhoid), $X_{7}$ (TB), dan $X_{8}$ (DBD). Keseluruhan data variabel diperoleh dari Dinas Kesehatan Kota Makassar. Dari 8 penyakit menular (variabel) tersebut tidak semuanya merupakan penderita penyakit menular, dua diantaranya baru merupakan suspect (terduga) saja karena belum dilakukan pemeriksaan laboratorium yaitu untuk penderita Campak $\left(X_{1}\right)$ dan Difteri $\left(X_{2}\right)$. Kedua penyakit menular ini tergolong dalam KLB (Kejadian Luar Biasa) karena telah dinyatakan punah namun masih muncul kembali. Apabila dalam analisis memiliki simbul $P X$, maka merupakan bagian dari Persentase jumlah penderita menurut jumlah penduduk. Berikut ini ditampilkan sampel data hasil penelitian (khusus untuk $X_{1}$, $X_{2}, P X_{1}$ dan $P X_{2}$, dimana $P X$ bermakna bahwa persentase $X$ berdasarkan $P$, sehingga bermakna data proporsional).

Studi ini lebih menitikberatkan pada persentase jumlah pasien penyakit menular daripada jumlahnya, walau keputusan ini memiliki aspek positif dan sedikit negatif (kalau dilihat sepintas saja). Aspek positifnya adalah dapat melihat langsung perbandingan antar kecamatan dan tidak mengurangi informasi data, dan aspek negatifnya hanya pada aspek jumlah pasien (pelapor/terduga/penderita), sebab membutuhkan proses transformasi lagi (Tabel 1).

Tabel 1. Sampel data hasil penelitian

\begin{tabular}{|clccccc|}
\hline No & Kecamatan & $\mathrm{P}$ & $\mathrm{X} 1$ & $\mathrm{X} 2$ & PX1 & PX2 \\
\hline 1 & Bontoala & $\mathbf{5 6 . 5 3 6}$ & $\mathbf{1 5}$ & 1 & $\mathbf{0 . 0 2 7}$ & 0.002 \\
2 & Mamajang & $\mathbf{6 1 . 0 0 7}$ & 0 & $\mathbf{1}$ & 0 & $\mathbf{0 . 0 0 2}$ \\
3 & Manggala & 94.714 & 34 & 0 & 0.036 & 0 \\
4 & Mariso & 59.292 & 3 & 0 & 0.005 & 0 \\
5 & Panakkukang & $\mathbf{1 9 1 . 7 2 8}$ & $\mathbf{3 2}$ & 2 & $\mathbf{0 . 0 1 7}$ & 0.001 \\
6 & Rappocini & $\mathbf{2 0 7 . 8 6 0}$ & 5 & $\mathbf{3}$ & 0.002 & $\mathbf{0 . 0 0 1}$ \\
7 & Tallo & 139.167 & 3 & 0 & 0.002 & 0 \\
8 & Tamalanrea & 112.170 & 7 & 1 & 0.006 & 0.001 \\
9 & Tamalate & 151.196 & 1 & 1 & 0.001 & 0.001 \\
10 & Ujung Pandang & 28.497 & 5 & 0 & 0.018 & 0 \\
11 & Ujung Tanah & 49.223 & 2 & 1 & 0.01 & 0.003 \\
12 & Wajo & 30.933 & 0 & 0 & 0 & 0 \\
13 & Makassar & 84.758 & 0 & 0 & 0 & 0 \\
14 & Biringkanaya & 202.520 & 16 & 1 & 0.008 & 0.001 \\
\hline
\end{tabular}

Tabel 1 hanya menampilkan dua penyakit menular yang hanya berupa suspek saja dan jumlahnya masih kurang dibandingkan dengan penyakit lainnya yang ribuan dan ratusan.

Studi ini mendapatkan hasil analisis deskriptif menunjukkan bahwa persentase tertinggi diberikan oleh Penderita Penyakit Diare pada semua kecematan se-Kota Makassar di Tahun 2018 ini. Persentase kedua diberikan oleh Kecacingan, itu nampak hanya pada satu kecamatan saja yaitu Kecamatan Ujungtanah dan di Ujungtanah juga didominasi oleh bagian Pulau Sangkarrang.
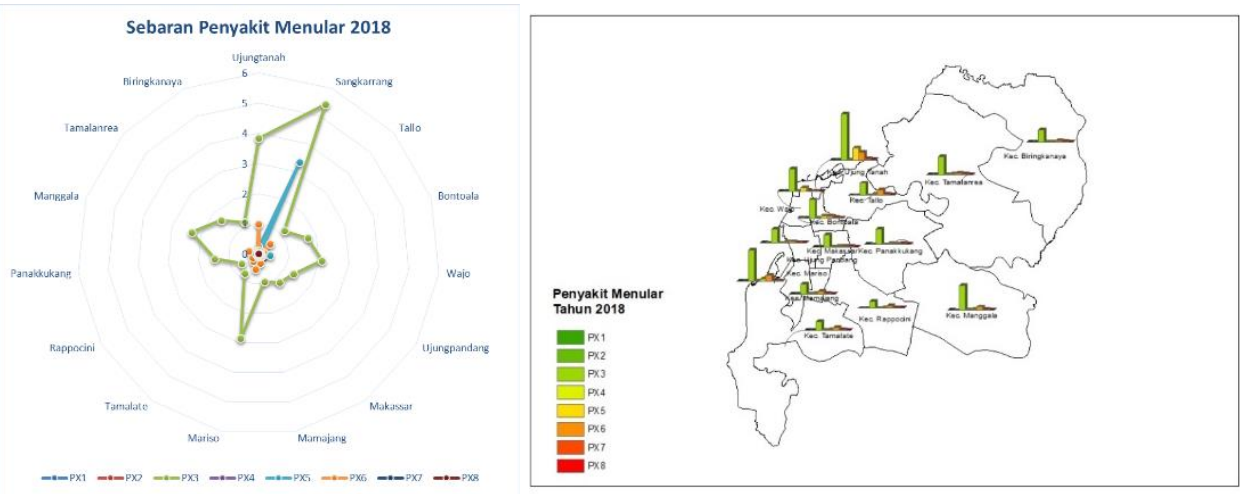

Gambar 2. Analisis Deskriptif untuk penyakit menular Kota Makassar 2018 
Gambar 2 menunjukkan dengan jelas bahwa peringkat empat besar penderita penyakit menular menurut kecamatan se-Kota Makassar di Tahun 2018 adalah (1) Diare di Sangkarrang (interval 5\% - 6\%), (2) Diare di Ujungtanah (interval 3\% - 4\%), (3) Kecacingan di Singkarang (interval 3\% - 4\%), dan (4) Diare di Mariso (interval 3\%-4\%). Kenyataannya adalah Singkarrang telah berpisah dengan Ujungtanah dan keduaduanya menempati urutan tertinggi dalam penyebaran penyakit menular.

Hasil analisis deskriptif juga menunjukkan bahwa rata-rata penyakit tertinggi terjadi pada Diare dan variansi tertinggi terjadi pada Kecacingan. Hal ini menunjukkan bahwa dua penyakit ini perlu diwaspadai karena memiliki rentan (kerawanan) untuk diderita oleh masyarakat Kota Makassar untuk Diare dan rentan karena ketakterduganya untuk Kecacingan. Jumlah kasus Diare adalah 20,700 kasus yang ditangani ke Puskesmas sepanjang Tahun 2018 dengan rata-rata sebanyak 1,380 kasus per-kecamatannya. Yang terendah adalah terduga (suspect) menderita penyakit difteri sebesar 11 kasus, walau ini belum dapat dikatakan penderita penuh karena belum dilakukan penanganan secara laboratorium. Namun, Difteri dan Campak adalah termasuk kasus kejadian luar biasa (KLB) dikarenakan oleh sebab dianggap sebagai penyakit yang telah punah dan muncul kembali. Urutan penyakit menular menurut jumlah penderitanya adalah Diare, Typhoid, Kecacingan, TB, DBD, Suspect Campak, Malaria, dan Suspect Difteri.

\section{PEMBAHASAN}

Analisis inferensial menggunakan univariate cluster index Moran dengan memperhatikan dimensi Low-High suatu penyakit dikaitkan dengan daerah (spasial) sekitarannya. Data yang dianalisis disini sepenuhnya adalah proposional data, yaitu proporsi data menurut jumlah penduduknya. Setelah itu dilakukan analisis inferensial untuk mengetahui tingkat kesignifikanan dari kejadian tersebut. Pada pembahasan ini menggunakan tambahan ilustrasi bergambar, hanya pada Penyakit Campak (suspect), lalu lainnya diberikan hanya hasil interpretasi saja.

\subsection{Penyakit (Suspect) Campak}

Jumlah pasien/kasus yang diduga menderita penyakit Campak adalah 15 orang (0.027\%) di Bontoala (jumlah penduduknya 56.536 jiwa) dan 32 orang $(0,027 \%$ ) di Panakkukang (jumlah penduduknya 191.728). Kedua kecamatan ini memiliki kasus yang berbeda, dimana jumlah terduga Campak di Panakkukang berjumlah dua kali lebih banyak daripada di Bontoala, walau proporsi keduanya justru terbalik (kasus di Bontoala lebih banyak 0,01\% daripada kasus di Panakkukang).

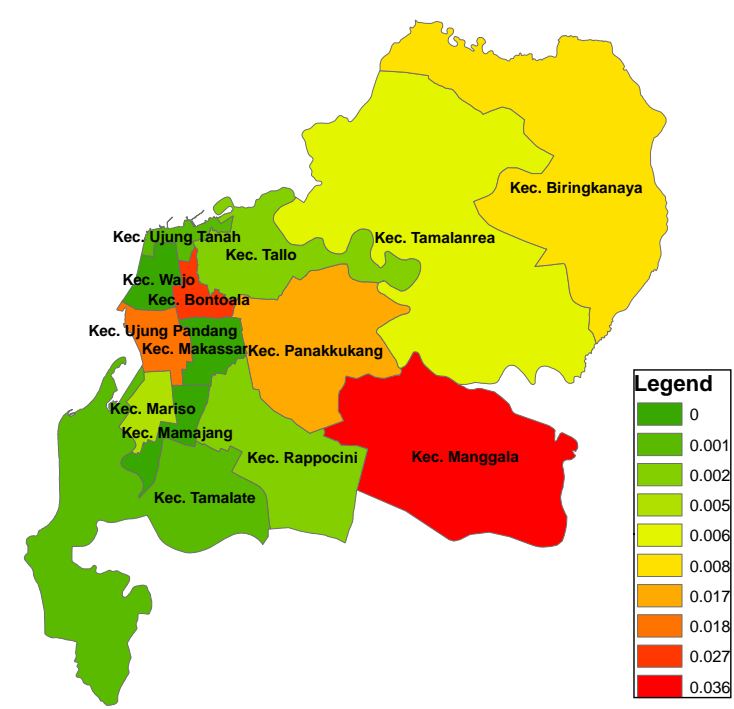

(a)

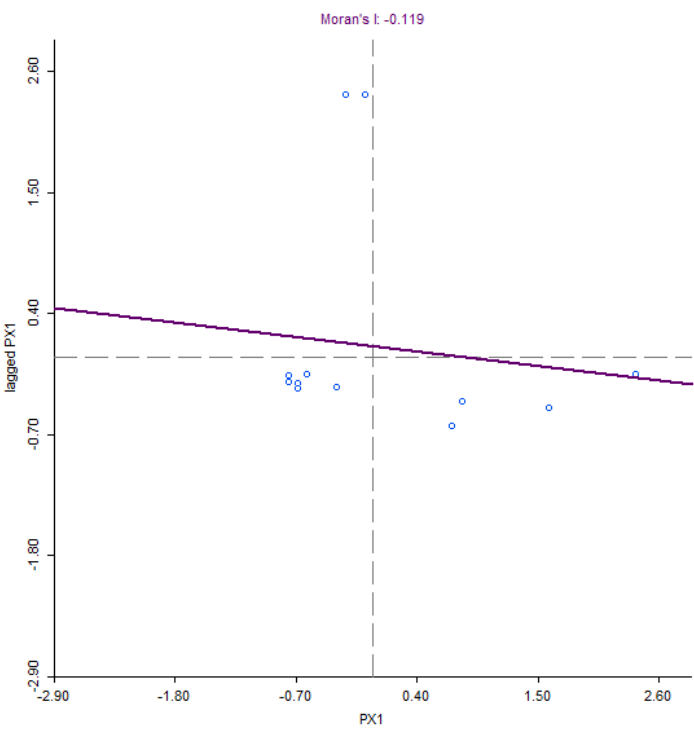

(b)

Gambar 3. Plot sebaran penderita Campak dan koefisien indeks Moran-nya

Proporsi penderita penyakit Campak (suspect) Kota Makassar 2018 menunjukkan (menggunakan software GeoDa) bahwa penderita penyakit menular Campak menurut kecamatan hanya tersebar hanya 
tersebar di 3 kuadran (Gambar 3b), yaitu Kuadran II (4 kecamatan), Kuadran III (8 kecamatan), dan Kuadran IV (2 kecamatan), dengan koefisien Indeks Moran sebesar -0,119. Hal ini menunjukkan bahwa ada 4 kecamatan yang High-Low (Kuadran II) yang memiliki jumlah penderita tinggi dan dikelilingi oleh daerah yang mempunyai penderita rendah, ada 8 kecamatan yang Low-Low (Kuadran III) yang memiliki jumlah penderita rendah dan juga dikelilingi oleh jumlah penderita yang rendah pula, dan ada 2 kecamatan yang Low-High (Kuadran IV) yang memiliki jumlah penderita rendah dan dikelilingi oleh daerah yang jumlah penderita tinggi.

Pada Gambar 3a menampilkan bahwa sebaran secara visualisasi dari posisi H-L adalah Kecamatan Manggala (diapit oleh Tamalanrea dan Rappocini), Panakkukang (diapit oleh Tamalanrea, Rappocini, Makassar), Bontoala (diapit oleh Tallo, Wajo, Makassar), dan Ujung Pandang (diapit oleh Wajo, Makassar, Mariso); pada posisi L-H adalah Biringkanaya (diapit oleh Tamalanrea), Tamalanrea (diapit oleh Tallo, Panakukang, Manggala, dan Biringkanaya); dan L-L ada 8 kecamatan dimana tiga diantaranya memiliki nilai yang sama (Kecamatan Makassar, Wajo, dan Mamajang) sehingga nampak seperti satu titik saja. Ilustrasi tersebut ditujukkan oleh Gambar 3.

Setelah menemukan pembagian posisi tiap kecamatannya, diperlukan tingkat keberartian posisi tersebut menggunakan uji LISA clustering (Gambar 4a) dan LISA significance (Gambar 4b) berikut ini.

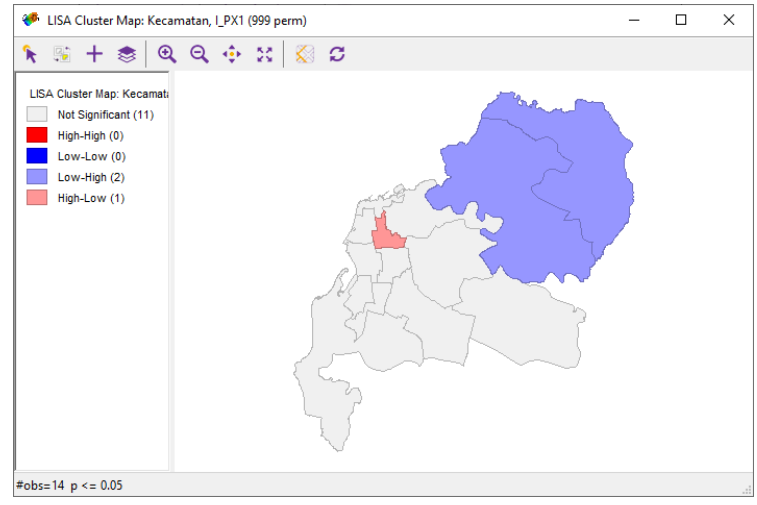

(a)

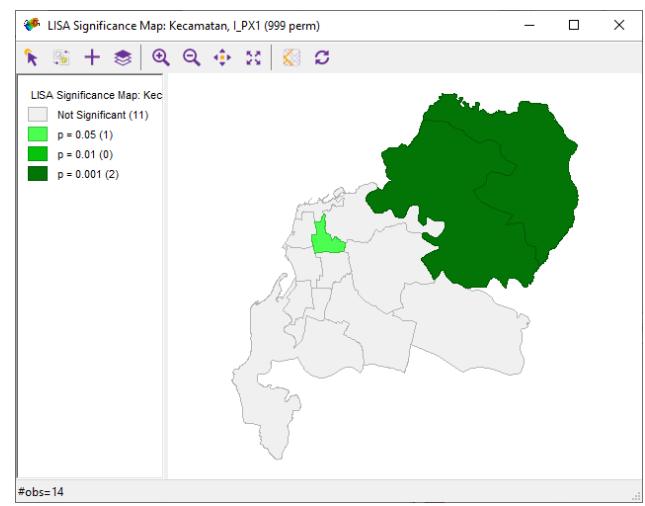

(b)

Gambar 4. Pengelompokan Spasial untuk Penyakit Campak Kota Makassar 2018

Berdasarkan hasil seperti Gambar 4, maka daerah yang signifikan bisa dimasukan pada kategori LowHigh (LH) yaitu hanya ada dua daerah, yaitu Kecamatan Biringkanaya dan Tamalanrea, daerah yang termasuk kategori High-Low (HL) yaitu hanya Kecamatan Bontoala. Tingkat kesignifikanan yang diberikan oleh ketiga kecamatan tersebut adalah kategori sangat signifikan $(\mathrm{p}=0.001)$ pada Kecamatan Biringkanaya dan Tamalanrea dan kategori signifikan rendah $(\mathrm{p}=0.05)$ hanya pada Kecamatan Bontoala. Dengan demikian, kecamatan yang lain tidak dapat dikatakan bisa terbagi pada posisi HL, LH, ataupun LL, namun pada taraf signifikan tersebut $(\mathrm{p}=0,05 ; 0,01 ; 0,001)$.

\subsection{Penderita (suspect) Difteri}

Jumlah pasien/kasus yang diduga menderita penyakit Difteri adalah 1 orang $(0.002 \%)$ di Mamajang (jumlah penduduknya 61.007 jiwa) dan 3 orang $(0,001 \%)$ di Rappocini (jumlah penduduknya 207.860 jiwa). Hal serupa di Campak, kedua kecamatan ini kasusnya berbeda jumlah, dimana Difteri di Rappocini berjumlah tiga kali lebih banyak daripada di Mamajang, walau proporsi keduanya justu terbalik (proporsi kasus di Mamajang lebih banyak dua kali daripada kasus di Rappocini).

Proporsi penderita penyakit Difteri (suspect) Kota Makassar 2018 menunjukkan bahwa mereka tersebar hanya tersebar di 3 kuadran saja, yaitu Kuadran I atau High-High (2 kecamatan), Kuadran II atau High-Low (5 kecamatan), dan Kuadran IV atau Low-High (1 kecamatan), dengan koefisien Indeks Moran sebesar $-0,138$.

Berdasarkan hasil analisis LISA (cluster dan significance) diperoleh bahwa hanya 2 kecamatan yang berada pada posisi HL (Kuadran II) yang signifikan dan itupun pada kategori sangat tinggi $(p=0,001)$. Kedua kecamatan tersebut adalah Kecamatan Tamalanrea dan Biringkanaya. 


\subsection{Penderita Diare}

Proporsi penderita penyakit Diare Kota Makassar 2018 menunjukkan bahwa mereka tersebar pada semua kuadran, dimana Kuadran I atau High-High (2 kecamatan), Kuadran II atau High-Low (2 kecamatan), Kuadran III atau Low-Low (1 kecamatan), dan Kuadran IV atau Low-High (9 kecamatan), dengan koefisien Indeks Moran sebesar -0,103.

Berdasarkan hasil analisis LISA (cluster dan significance) diperoleh bahwa hanya 1 kecamatan yang berada signifikan itupun pada kategori signifikansi rendah $(\mathrm{p}=0,05)$ yaitu pada kuadran III atau Low-Low yang diberikan oleh Kecamatan Pannakukang. Hal ini menunjukkan bahwa Kecamatan Panakkukang memiliki kasus rendah dan dikelilingi oleh daerah/kecamatan yang memilik persentasi kasus rendah.

\subsection{Penderita Malaria}

Proporsi penyakit Malaria Kota Makassar 2018 menunjukkan bahwa mereka tersebar pada semua kuadran, dimana Kuadran I atau High-High (7 kecamatan), Kuadran II atau High-Low (3 kecamatan), Kuadran III atau Low-Low (3 kecamatan), dan Kuadran IV atau Low-High (1 kecamatan), dengan koefisien Indeks Moran sebesar -0,046.

Hasil analisis LISA (cluster dan significance) diperoleh bahwa hanya 1 kecamatan yang berada pada kategori sangat signifikan $(\mathrm{p}=0,001)$ dan pada posisi High-Low yang diberikan oleh Kecamatan Ujungtanah. Hal ini menunjukkan bahwa Kecamatan Ujungtanah memiliki kasus tinggi dan dikelilingi oleh daerah/kecamatan yang memilik persentasi kasus rendah.

\subsection{Penderita Kecacingan}

Proporsi penyakit Kecacingan Kota Makassar 2018 menunjukkan bahwa mereka tersebar pada semua kuadran, dimana Kuadran I atau High-High (2 kecamatan), Kuadran II atau High-Low (1 kecamatan), Kuadran III atau Low-Low (4 kecamatan), dan Kuadran IV atau Low-High (7 kecamatan), dengan koefisien Indeks Moran sebesar -0,059.

Hasil analisis LISA (cluster dan significance) diperoleh bahwa hanya 4 kecamatan yang berada pada kategori signifikan rendah $(\mathrm{p}=0,05)$ dan pada posisi Low-Low sebanyak 1 kecamatan dan 3 kecamatan pada posisi Low-High. Daerah yang termasuk kategori Low-Low (LL) yaitu daerah dengan penderita Kecacingan rendah, dan dikelilingi oleh daerah dengan jumlah penderita yang rendah yaitu Kecamatan Manggala, daerah yang termasuk kategori Low-High (LH) yaitu daerah dengan jumlah penderitanya rendah dan dikelilingi oleh daerah dengan jumlah penderita tinggi, ada tiga daerah yaitu Kecamatan Rappocini, Makassar, dan Ujungpandang.

\subsection{Penderita Typhoid}

Proporsi penyakit Typhoid Kota Makassar 2018 menunjukkan bahwa mereka tersebar pada tiga kuadran, dimana Kuadran I atau High-High (4 kecamatan), Kuadran II atau High-Low (3 kecamatan), dan Kuadran IV atau Low-High (7 kecamatan), dengan koefisien Indeks Moran sebesar -0,116.

Hasil analisis LISA (cluster dan significance) diperoleh bahwa seluruh kecamatan belum dapat menunjukkan signifikan berbeda dengan yang lainnya.

\subsection{Penderita TB}

Proporsi penyakit Tubercolosis (TB) Kota Makassar 2018 menunjukkan bahwa tersebar pada semua kuadran, dimana Kuadran I atau High-High (1 kecamatan), Kuadran II atau High-Low (1 kecamatan), Kuadran III atau Low-Low (5 kecamatan), dan Kuadran IV atau Low-High (7 kecamatan), dengan koefisien Indeks Moran sebesar -0,051.

Hasil analisis LISA (cluster dan significance) diperoleh bahwa seluruh kecamatan belum dapat menunjukkan signifikan berbeda dengan yang lainnya.

\subsection{Penderita DBD}

Proporsi penyakit Demam Berdarah Dengue (DBD) Kota Makassar 2018 menunjukkan bahwa tersebar pada tiga kuadran saja, yaitu Kuadran I atau High-High (4 kecamatan), Kuadran II atau High-Low (3 kecamatan), dan Kuadran IV atau Low-High (7 kecamatan), dengan koefisien Indeks Moran sebesar -0,143. 
Hasil analisis LISA (cluster dan significance) diperoleh bahwa hanya 1 kecamatan yang berada pada kategori signifikan rendah $(\mathrm{p}=0,05)$ dan pada posisi High-Low yaitu Kecamatan Panakkukang. Artinya, Kecamatan Panakukang memiliki proporsi kasus DBD tinggi dan diapit oleh kecamatan yang memiliki kasus rendah.

\section{KESIMPULAN}

Ada beberapa kesimpulan menarik yang dapat diambil dari kajian ini, antara lain adalah (1) keterbatasan jumlah penyakit terjadi karena beberapa kendala lapangan, seperti ada dua kasus penyakit menular yang belum bisa diambil sebagai jumlah penderitanya, yaitu kasus penyakit menular Campak dan Difteri, ada kasus yang tidak boleh diambil sebagai data Kota Makassar seperti Kusta karena banyak pasien merupakan pendatang dari kabupaten lain, ada juga kasus yang tidak boleh diambil karena keamanan dan tidak bisa menunjukkan kasus lokasi setempat, yaitu HIV. Oleh karena itu, penelitian ini hanya bertolak pada 8 kasus penyakit menular saja yaitu Suspect Campak, Suspect Difteri, Diare, Kecacingan, Malaria, Typhoid, DBD, TB; (2) mengacu pada hasil penelitian diperoleh ada dua peringkat tertinggi dilihat dari kaitan antara penyakit dan lokasi adalah (a) Diare di Sangkarrang, Ujungtanah, dan Mariso, (b) Kecacingan di Singkarang; (3) berdasar pada analisis univariate cluster index Moran serta ditampilkan secara visual pola penyebaran pasien penderita penyakit menular di setiap kecamatan se-Kota Makassar 2018 diperlihatkan dalam bentuk peta tematik (walau dalam artikel ini hanya diwakili satu penyakit saja) dan tersebar dari tidak ada satupun yang signifikan sampai dengan kategori sangat signifikan, adapun hasil menunjukkan bahwa pola penyebaran dan keterkatian penyakit dengan kecamatannya di Kota Makassar 2018 tidak merata dan cenderung terjadi pada kecamatan-kecamatan tertentu saja yaitu untuk penyakit (a) Campak ada 3 kecamatan (Biringkanaya, Tamalanrea, dan Bontoala), (b) Difteri ada 2 kecamatan (Tamalanrea dan Biringkanaya), (c) Diare hanya di Kecamatan Panakkukang, (d) Malaria hanya di Ujungtanah, (e) Kecacingan di 4 kecamatan (Manggala, Rappocini, Makassar, dan Ujungpandang), (f) DBD hanya di Kecamatan Panakkukang, (g) Typhoid dan TB tak signifikan.

\section{UCAPAN TERIMA KASIH}

Artikel ini adalah hasil penelitian yang dibiayai oleh DIPA Universitas Negeri Makassar, Nomor: SP DIPA - 042.01:2.400964/2019, Tanggal 5 Desember 2018. Sesuai Surat Keputusan Rektor Universitas Negeri Makassar, Nomor: 2117/UN36/KP/2019, Tanggal 5 Maret 2019. Oleh karena itu, ucapan terima kasih dihaturkan kepada jajaran pimpinan Universitas Negeri Makassar, terkhusus bagi Rektor, Ketua LP2M, Dekan FMIPA, Ketua Jurusan Matematika, dan Ketua Program Studi Matematika, serta semua pihak yang tak mampu disebutkan namanya satu-persatu.

\section{DAFTAR PUSTAKA}

[1] E. Sadewo, I. Syabri, and Pradono, "Dampak Post-Suburbanisasi dan Pertumbuhan Perkotaan di Kawasan Pinggiran Metropolitan Jabodetabek Terhadap Kerentanan Bencana Banjir," J. GREEN GROWTH DAN Manaj. Lingkung., 2018, doi: 10.21009/jgg.071.01.

[2] I. Wardi, I. Laksmiwati, I. Gunadi, and A. As-syakur, "Dampak Pertumbuhan Penduduk Terhadap Lingkungan Dan Budaya Subak: Studi Kasus Di Kabupaten Tabanan Provinsi Bali,” Bumi Lestari, vol. 14, no. 2, pp. 110 124, 2014.

[3] S. Seran, "Hubungan antara Pendidikan, Pengangguran, dan Pertumbuhan Ekonomi dengan Kemiskinan," J. Ekon. Kuantitatif Terap., vol. 10, no. 1, pp. 59-71, 2017, doi: 10.24843/jekt.2017.v10.i01.p07.

[4] A. A. Putri, W. Sanusi, and Sukarna, "Model Regresi Spasial dan Aplikasinya pada Kasus Tingkat Kemiskinan Kabupaten Soppeng," Indones. J. Fundam. Sci., vol. 4, no. 2, pp. 102-109, 2018.

[5] Aswi and Sukarna, "Spatial Distribution Analysis of Dengue Incidence in Makassar, Indonesia," Int. J. Appl. Math. Stat., vol. 53, no. 6, pp. 202-208, 2015.

[6] C. Christiani, P. Tedjo, and B. Martono, "Analisis Dampak Kepadatan Penduduk Terhadap Kualitas Hidup Masyarakat Provinsi Jawa Tengah,” J. Ilm. Untag Semarang, vol. 3, no. 1, pp. 102-114, 2014. 
[7] R. N. Kurniawan K., L. Renjaan, and A. Yani, "Keyakinan Masyarakat Terhadap Penyebab Hipertensi, Dan Upaya Penanggulangannya,” MPPKI (Media Publ. Promosi Kesehat. Indones. Indones. J. Heal. Promot., vol. 2, no. 1, pp. 1-4, 2019, doi: 10.31934/mppki.v2i1.521.

[8] N. Mboi et al., "On the road to universal health care in Indonesia, 1990-2016: a systematic analysis for the Global Burden of Disease Study 2016," Lancet, vol. 392, no. 10147, pp. 581-591, 2018, doi: 10.1016/S01406736(18)30595-6.

[9] Haider, “Antisipasi Penyakit Menular, Dinkes Makassar Gelar Worshop Sistem Kewaspadaan Dini dan Respon," MakassarMetro.com, Makassar, 03-Sep-2019.

[10] W. I. . Rajabidfard A, "Spatial Data Infrastructures Model for Developing Countries: A Case Study of Nigeria," Thesis, 2009.

[11] Abdul Kadir, Pengenalan Sistem Informasi Edisi Revisi. Yogyakarta: Andi Offset, 2014.

[12] A. Kristanto, Perancangan Sistem Informasi dan Aplikasinya. Yogyakarta: Gava Media, 2013.

[13] D. W. S. Wong and J. Lee, Statistical Analysis of Geographic Information with ArcView GIS and ArcGIS. Hoboken, New Jersey: John Wiley \& Sons, Inc, 2005.

[14] R. H. Shumway and J. C. Davis, "Statistics and Data Analysis in Geology," Technometrics, vol. 29, no. 4, 1987, doi: $10.2307 / 1269470$.

[15] K. McGarigal and B. J. Marks, "FRAGSTATS: spatial pattern analysis program for quantifying landscape structure," 1995.

[16] S. H. Handoko, E. Sediono, and S. Suhartono, "Sistem Informasi Geografis Berbasis Web untuk Pemetaan Sebaran Alumni Menggunakan Metode K-Means,” J. Sist. Inf. BISNIS, 2014, doi: 10.21456/vol1 iss2pp80-85.

[17] I. Indarto and A. Faiso, Konsep Dasar Analisis Spasial. Yogyakarta: Andi Offset, 2013.

[18] M. A. Tiro, Sukarna, and Aswi, Statistika Deskriptif Peubah Banyak. Makassar: Andira Publisher, 2010.

[19] W. Agus, Analisis Statistika Multivariat Terapan. Yogyakarta: Sekolah Tinggi Ilmu Manajemen YKPN, 2010. 
